\title{
Potensi Khamir sebagai Agens Pengendalian Hayati Colletotrichum capsici, Cendawan Penyebab Antraknosa pada Buah Cabai
}

\author{
Potency of Yeast as Biological Control Agent of Colletotrichum capsici; \\ Fungal Causing Antrachnose in Chilli.
}

Okky Setyawati Dharmaputra $^{1 *}$, Lisdar I. Sudirman $^{1}$, Maria Magdalena Misnawati ${ }^{1}$

Diterima 21 Desember 2015/Disetujui 06 Juli 2016

\begin{abstract}
Antrachnose on chilli fruit caused by Colletotrichum capsici can reduce yield and quality of chilli fruit. Biological control agent can be used as an alternative to control $\underline{C}$. capsici. Yeast is one of biological control agent which is potential to control the pathogen. This study was aimed at testing antagonistic potential of yeast on fruits and vegetables against $\underline{C}$. capsici. Twenty two yeast isolates were isolated from banana, rambutan, red chilli, tomato, and eggplant fruits. Screening for antagonistic yeast using well test showed that 5 isolates of yeast (CMM-1, CMM-3, CMM-4, TMM1, and EMM-11) completely inhibited the growth of $\underline{C}$. capsici. Based on the result of biocontrol assay of the pathogen in vivo, four yeast isolates (CMM-3, CMM-4, TMM-1, and EMM-11) completely inhibited $\underline{C}$. capsici in vivo. Identification using morphological and molecular characteristics showed that these four yeast isolates were Issatchenkia orientalis.
\end{abstract}

Keywords: antagonistic yeast, antrachnose, biocontrol, Issatchenkia orientalis

\begin{abstract}
ABSTRAK
Antraknosa pada buah cabai yang disebabkan oleh Colletotrichum capsici dapat menyebabkan penurunan produksi dan kualitas buah cabai. Penggunaan agens pengendalian hayati dapat menjadi salah satu alternatif untuk mengendalikan $C$. capsici. Khamir merupakan salah satu agens pengendalian hayati yang berpotensi mengendalikan C. capsici. Penelitian ini bertujuan menguji potensi antagonistik khamir pada buah-buahan dan sayuran terhadap C. capsici. Sebanyak 22 isolat khamir diisolasi dari buah rambutan, pisang, cabai merah besar, tomat, dan terung ungu. Seleksi khamir antagonis menggunakan uji sumur diperoleh sebanyak 5 isolat khamir, yaitu isolat CMM-1, CMM-3, CMM-4, TMM-1, dan EMM-11 menghambat total pertumbuhan C. capsici. Isolat CMM-3, CMM-4, TMM-1, dan EMM-11 menghambat total pertumbuhan C. capsici in vivo. Berdasarkan hasil identifikasi secara morfologi dan molekuler, isolat CMM-3, CMM-4, TMM-1, dan EMM-11 adalah Issatchenkia orientalis.
\end{abstract}

Kata kunci: antraknosa, Issatchenkia orientalis, khamir antagonis, pengendalian hayati

\section{PENDAHULUAN}

Menurut Kementan (2015) di Indonesia pada tahun 2013 produksi cabai merah besar adalah 1012879 ton. Adanya organisme pengganggu tanaman dapat menyebabkan penurunan produksi dan mutu buah cabai merah. Salah satu organisme pengganggu tanaman yang dapat menyerang tanaman cabai merah adalah Colletotrichum capsici. Serangan $C$. capsici dapat terjadi pada saat tanaman cabai masih di lapangan (prapanen) dan pascapanen. Colletotrichum capsici menyebabkan penyakit antraknosa pada buah 
cabai merah. Selama ini, usaha pengendalian pascapanen serangan $C$. capsici pada buah cabai yang dilakukan oleh petani adalah menggunakan fungisida sintetik yang dianggap lebih cepat dan efektif. Penggunaan fungisida sintetik secara terus-menerus dapat menimbulkan berbagai masalah karena fungisida sintetik sulit terdegradasi secara alami. Masalah yang timbul akibat penggunaan fungisida sintetik yaitu timbulnya resistensi patogen dan adanya residu pada bahan pangan yang bersifat karsinogenik (Pal et al., 2006). Hal ini menyebabkan diperlukannya suatu agens pengendalian hayati C. capsici yang aman, baik untuk manusia maupun lingkungan.

Beberapa agens pengendalian hayati antraknosa pada buah cabai yang telah dilaporkan adalah khamir Pichia guilliermondii, Candida musae, C. quercitrusa, dan Issatchenkia orientalis. Efikasi pengendalian hayati $C$. capsici tertinggi yaitu disebabkan oleh $P$. guiliermondii (93.3\%), diikuti oleh C. musae (83.1\%), I. orientalis (76.6\%) dan C. quercitrusa (66.4\%). (Chanchaichaovivat et al., 2007). Wilia et al. (2012) melaporkan bahwa Cryptococcus terreus, C. albidus var aerius IPB 1, C. albidus var aerius IPB 2, Candida edax dan isolat CBN masing-masing dapat mengendalikan C. capsici sebesar 62.5, 57.5, $52.5,62.5$ dan $87.5 \%$. Penelitian pada tanaman cabai menunjukkan bahwa aplikasi dengan mulsa organik dapat meningkatkan pertumbuhan dan hasil buah cabai yang baik (Harsono, 2012).

Penggunaan khamir sebagai agens pengendalian hayati memiliki beberapa kelebihan, yaitu khamir mudah diperbanyak dalam waktu singkat, tidak menghasilkan toksin, mampu mengkolonisasi dan bertahan pada permukaan buah dalam waktu yang cukup lama pada berbagai kondisi (Hashem dan Alamri, 2009). Tujuan penelitian ini adalah menguji potensi isolat-isolat khamir yang diisolasi dari buah-buahan dan sayuran untuk mengendalikan $C$. capsici pada buah cabai.

\section{BAHAN DAN METODE}

\section{Pengambilan Sampel Buah-buahan dan Sayuran}

Pada penelitian ini buah-buahan dan sayuran yang sehat dan digunakan untuk isolasi khamir adalah pisang ambon (Ditbuah 2012), rambutan varietas Binjai, tomat varietas Betavila dan Servo, cabai merah besar varietas Adipati dan Imperial-308, terung ungu varietas Mustang, Yumi dan Largo (Ditbenih, 2014), diperoleh dari beberapa pasar tradisional di Kota Bogor dan sekitarnya. Buah cabai merah besar yang digunakan pada uji pengendalian C. capsici in vivo adalah buah cabai merah besar varietas Gada (Ditbenih, 2014) yang diperoleh dari Toko Buah Total, Bogor.

\section{Asal Isolat C. capsici}

Pada penelitian ini isolat C. capsici yang digunakan adalat isolat BIO 51047, diperoleh dari koleksi biakan SEAMEO BIOTROP, Bogor.

\section{Isolasi Khamir dari Buah-buahan dan Sayuran}

Isolasi khamir pada pisang, rambutan, tomat, cabai merah besar, dan terung ungu dilakukan berdasarkan metode pengenceran berseri 1:10 sampai 1:1000 yang dilanjutkan dengan metode cawan sebar. Sebanyak $0.1 \mathrm{~mL}$ dari setiap pengenceran diambil menggunakan pipet, kemudian disebar pada media Yeast Malt Extract Agar (YMEA) yang mengandung kloramfenikol (100 $\left.\mathrm{mg} \mathrm{L}^{-1}\right)$ menggunakan batang gelas berbentuk segitiga (Chanchaichaovivat et al., 2007). Selanjutnya, semua cawan diinkubasi selama 48 jam pada suhu ruang $\left(28 \pm 2{ }^{\circ} \mathrm{C}\right)$. Setiap koloni khamir yang berbeda ciri-cirinya berdasarkan pengamatan secara visual dan dari pengenceran yang memberikan koloni terpisah dimurnikan pada media YMEA tanpa kloramfenikol, kemudian dibiakkan pada media Nutrient Yeast Dextrose Agar (NYDA). Setiap koloni khamir tersebut selanjutnya disebut isolat.

\section{Seleksi Khamir Antagonis terhadap C. capsici}

Seleksi khamir antagonis terhadap $C$. capsici dilakukan menggunakan uji sumur (well test) berdasarkan metode Dan et al. (2003). Sebanyak 5 potong biakan murni setiap isolat khamir (diameter $5 \mathrm{~mm}$ ) dibiakkan pada $25 \mathrm{~mL}$ media Nutrient Yeast Dextrose Broth (NYDB) di dalam labu erlenmeyer volume $100 \mathrm{~mL}$, kemudian diinkubasi pada suhu $28 \pm 2{ }^{\circ} \mathrm{C}$ selama 7 hari dan digoyangkan selama 1 jam setiap 24 jam 
menggunakan shaker merek Kottermann 4020. Sel-sel khamir diendapkan melalui sentrifugasi menggunakan sentrifuse mikro $200 \mathrm{R}$ (jenis rotor sentrifuse adalah fixed-angle rotor) dengan kecepatan $7000 \mathrm{rpm}$ selama 15 menit dan dibilas dua kali menggunakan akuades steril, selanjutnya disuspensikan kembali di dalam akuades steril hingga konsentrasinya mencapai $5 \times 10^{8}$ sel $\mathrm{mL}^{-1}$. Sel khamir dihitung menggunakan hemasitometer.

Bagian tengah media PDA yang mengandung $15 \%$ jus buah cabai merah var. IPB Perbani di dalam cawan petri (diameter 9 $\mathrm{cm})$ dibuat sumur menggunakan cork-borer (diameter $6 \mathrm{~mm}$ ), kemudian suspensi sel khamir $\left(20 \mu \mathrm{L}\right.$ dari $5 \times 10^{8}$ sel $\left.\mathrm{mL}^{-1}\right)$ ditempatkan di dalam sumur menggunakan pipet mikro. Cawan petri dibiarkan selama 2 jam supaya suspensi sel khamir berdifusi ke dalam sumur. Selanjutnya, $20 \mu \mathrm{L}$ dari $5 \times 10^{6}$ konidium $\mathrm{mL}^{-1}$ C. capsici ditempatkan di dalam sumur. Sebagai kontrol, pada sumur tidak diberi suspensi sel khamir. Setiap perlakuan (setiap isolat khamir) dan kontrol dibuat 3 ulangan (= 3 cawan petri). Semua cawan diinkubasi pada suhu ruang $\left(28 \pm 2{ }^{\circ} \mathrm{C}\right)$ dalam kondisi gelap. Pertumbuhan C. capsici pada setiap cawan diamati berdasarkan keberadaan koloninya setelah 7 hari inkubasi. Isolat khamir yang menghambat total pertumbuhan $C$. capsici setelah 7 hari inkubasi digunakan pada uji pengendalian hayati $C$. capsici in vivo.

\section{Pengendalian Hayati $C$. capsici Menggunakan Khamir In Vivo.}

Pengendalian hayati penyakit tanaman yaitu penggunaan mikrob (mikroorganisme) antagonis untuk menekan penyakit ( $\mathrm{Pal}$ et al., 2006). Pengendalian hayati $C$. capsici menggunakan khamir in vivo dilakukan berdasarkan metode Dan et al. (2003). Buah cabai merah besar varietas Gada yang sehat, tidak ada luka dan goresan pada permukaan buah, serta tidak diberi perlakuan pestisida dibilas dengan air leding. Setelah dikeringudarakan, permukaan buah cabai merah didesinfeksi dengan cara diseka menggunakan kapas steril yang telah dibasahi etanol $70 \%$. Sebanyak $20 \mu \mathrm{L}$ suspensi sel setiap isolat khamir dengan konsentrasi $5 \times 10^{8} \mathrm{sel} \mathrm{mL}^{-1}$ dan ditambahkan $0.1 \%$ Tween 20 diinokulasikan pada bagian tengah buah cabai menggunakan suntikan plastik merek Concepon. Setelah 2 jam inokulasi khamir, sebanyak $20 \mu \mathrm{L}$ konidium C. capsici $\left(5 \times 10^{6}\right.$ konidium $\left.\mathrm{mL}^{-1}\right)$ dan ditambahkan $0.1 \%$ Tween 20 diinokulasikan pada titik inokulasi yang sama dengan inokulasi khamir pada buah cabai merah. Sebagai kontrol negatif, buah cabai merah hanya diinokulasi dengan $20 \mu \mathrm{L}$ konidium C. capsici $\left(5 \times 10^{6}\right.$ konidium $\left.\mathrm{mL}^{-1}\right)$, sedangkan sebagai kontrol positif digunakan $20 \mu \mathrm{L}$ larutan fungisida benomil $0.5 \%$ dan 20 $\mu \mathrm{L}$ suspensi konidium C. capsici $\left(5 \times 10^{6}\right.$ konidium $\mathrm{mL}^{-1}$ ). Setiap perlakuan dan kontrol dibuat 12 ulangan (= 12 buah cabai). Buah cabai merah ditempatkan di dalam wadah plastik dengan diameter atas $18 \mathrm{~cm}$, diameter bawah $14 \mathrm{~cm}$, tinggi $15 \mathrm{~cm}$, dan volume $3 \mathrm{~L}$ (4 buah cabai per wadah plastik) yang telah didesinfeksi menggunakan etanol $70 \%$. Kondisi di dalam wadah dibuat lembab (kelembaban relatif 90\%). Semua wadah ditutup dengan kain batis steril, selanjutnya diinkubasi pada suhu ruang $\left(28 \pm 2{ }^{\circ} \mathrm{C}\right)$ selama 7 hari. Pengamatan gejala antraknosa dilakukan terhadap luas permukaan buah cabai merah yang terserang $C$. capsici dengan metode gravimetri (Rindita et al., 2015) Persentase hambatan antraknosa dihitung berdasarkan rumus berikut:

$\mathrm{H}=\frac{\mathrm{LK}-\mathrm{LP}}{\mathrm{LK}} \times 100 \%$

$\mathrm{H}$ : hambatan antraknosa (\%)

LK : luas gejala antraknosa pada kontrol negatif $\left(\mathrm{mm}^{2}\right)$

LP : luas gejala antraknosa pada perlakuan $\left(\mathrm{mm}^{2}\right)$

\section{Analisis Data}

Rancangan penelitian yang digunakan pada seleksi khamir antagonis dan uji pengendalian hayati $C$. capsici menggunakan khamir in vivo adalah rancangan acak lengkap masing-masing dengan 3 dan 12 ulangan (Mattjik dan Sumertajaya, 2002). Tiga ulangan (= 3 cawan petri) yaitu pada tahap penelitian seleksi khamir antagonis terhadap C. capsici, sedangkan 12 ulangan (= 12 buah cabai) yaitu pada tahap penelitian pengendalian hayati $C$. capsici menggunakan khamir in vivo. Analisis statistika dilakukan menggunakan program SPSS versi 22.0. Jika analisis ragam (ANOVA) memberikan perbedaan yang nyata, maka dilakukan uji lanjut (DMRT) banding Duncan. 


\section{Identifikasi Khamir Antagonis Secara Morfologi dan Molekuler}

Isolat khamir yang menghambat total perumbuhan $C$. capsici in vivo diidentifikasi secara morfologi berdasarkan pustaka Kurtzman et al. (2011). Setiap isolat khamir ditumbuhkan pada media Malt Extract Agar (MEA) selama 7 hari pada suhu $28 \pm 2{ }^{0} \mathrm{C}$. Warna, bentuk, tepi, dan elevasi koloni setiap isolat khamir diamati, kemudian dibuat preparat menggunakan pewarna laktofenol biru katun. Ciri-ciri setiap sel khamir diamati menggunakan mikroskop Olympus.

Identifikasi khamir secara molekuler dilakukan di Laboratorium Biorin PPSHB IPB berdasarkan pustaka Mitchell et al. (1992). Primer yang digunakan adalah primer umum $18 \mathrm{~S}$ rDNA dengan forward primer ITS1 dan reverse primer ITS4. Fragmen DNA hasil amplifikasi dikirim ke PT Genetica Science untuk sikuensing. Analisis homologi gen khamir dilakukan menggunakan basic local alignment search tool (BLAST) pada situs National Center for Biotechnology Information (NCBI) (www.blast.ncbi.nlm. nih.gov).

\section{HASIL DAN PEMBAHASAN}

\section{Khamir pada Buah-buahan dan Sayuran}

Sebanyak 22 isolat khamir berhasil diisolasi dari permukaan buah-buahan dan sayuran yang sehat, yaitu isolat CMM-1, CMM-3, CMM-4, PMM-1, PMM-3, TMM1,TMM-6, RMM-1, EMM-1, EMM-2, EMM4, EMM-5, EMM-9, EMM-10, EMM-11, EMM-13, EMM-14, EMM-15, EMM-16, EMM-17, EMM-18, dan EMM-19. Kode isolat khamir pada permukaan buah-buahan dan sayuran yang diperoleh dari beberapa pasar tradisional di Kota Bogor dan sekitarnya dapat dilihat pada Tabel 1.

Tabel 1. Kode isolat khamir pada permukaan buah-buahan dan sayuran yang diperoleh dari beberapa pasar tradisional di Kota Bogor dan sekitarnya

\begin{tabular}{lcc}
\hline Sampel Buah-buahan dan Sayuran & Lokasi Pengambilan Sampel & Kode Isolat* \\
\hline Cabai merah var. Adipati & Pasar Gunung Batu & CMM-1 \\
& & CMM-3 \\
Cabai merah var. Imperial & Pasar Bogor & CMM-4 \\
Pisang ambon & Pasar Bogor & PMM-1 \\
& & PMM-3 \\
Tomat var. Betavila & Pasar Gunung Batu & TMM-1 \\
Tomat var. Servo & Pasar Anyar & TMM-6 \\
Rambutan var. Binjai & Pasar Dramaga & RMM-1 \\
Terung var. Mustang & Pasar Gunung Batu & EMM-2 \\
& & EMM-4 \\
& & EMM-5 \\
& & EMM-10 \\
Terung var. Yumi & Pasar Bogor & EMM-1 \\
& & EMM-9 \\
Terung var. Yumi & Pasar Anyar & EMM-11 \\
& & EMM-14 \\
& & EMM-15 \\
Terung var. Largo & Pasar Gembrong & EMM-13 \\
& & EMM-16 \\
& & EMM-17 \\
& & EMM-18 \\
& & EMM-19 \\
\hline Keterangan: *Kode isolat berdasarkan (a) huruf pertama nama buah-buahan dan sayuran, misal C = Cabai, P = \\
Pisang, R = Rambutan, E = Egg plant; (b) MM = singkatan nama mahasiswa yang terlibat pada \\
penelitian. Angka 1 pada CMM-1 yaitu isolat khamir pertama kali yang diisolasi dari cabai merah var. \\
Adipati.
\end{tabular}




\section{Khamir Antagonis terhadap C. capsici}

Hasil analisis ragam menunjukkan perlakuan 22 isolat khamir dan kontrol menghasilkan luas koloni $C$. capsici yang berbeda sangat nyata pada taraf kepercayaan 99\% (Tabel 2). Berdasarkan hasil seleksi khamir menggunakan uji sumur, diperoleh 5 dari 22 isolat khamir yang menghambat total pertumbuhan $C$. capsici karena berdasarkan pengamatan secara visual tidak ada pertumbuhan miselium $C$. capsici pada media PDA yang mengandung $15 \%$ jus cabai merah (Gambar 1).

Kelima isolat tersebut adalah isolat CMM-1 dan CMM-3 yang diisolasi dari buah cabai merah besar var. Adipati, isolat CMM-4 yang diisolasi dari cabai merah besar var. Imperial, isolat TMM-1 yang diisolasi dari tomat var. Betavila, dan isolat EMM-11 yang diisolasi dari terung ungu var. Yumi.

\section{Pengendalian Hayati C. capsici Menggunakan Khamir In Vivo}

Strategi umum pengendalian hayati adalah menggunakan organisme hidup sebagai agens pengendalian hayati penyakit prapanen dan pascapanen pada buah-buahan dan sayuran (Janisiewicz dan Korsten, 2002). Menurut Sharma et al. (2009) pengendalian penyakit pascapanen lebih efektif dan efisien daripada pengendalian prapanen.

Tabel 2. Analisis ragam hasil seleksi khamir antagonis menggunakan uji sumur

\begin{tabular}{|c|c|c|c|c|}
\hline Sumber Keragaman & Jumlah Kuadrat & $\mathrm{db}$ & Kuadrat Tengah & F-Hitung \\
\hline A & $2.708 \mathrm{E} 7$ & 22 & 1230725.125 & $72.284^{* *}$ \\
\hline Galat & 783203.571 & 46 & 17026.165 & \\
\hline Total & $2.786 \mathrm{E} 7$ & 68 & & \\
\hline
\end{tabular}

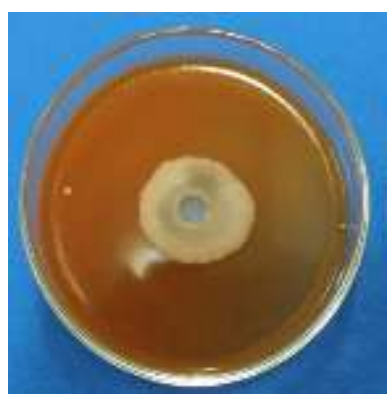

a

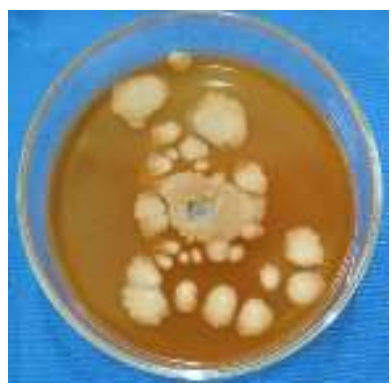

d

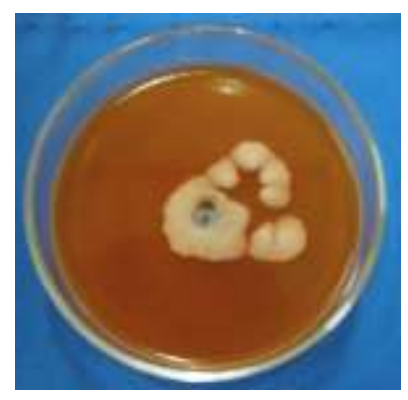

b

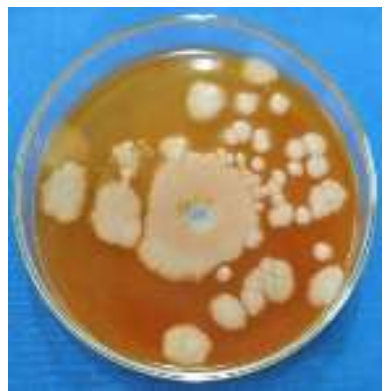

$\mathrm{e}$

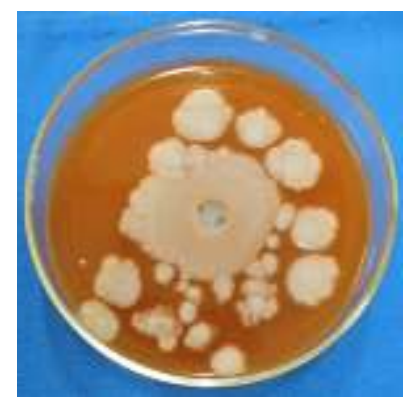

c

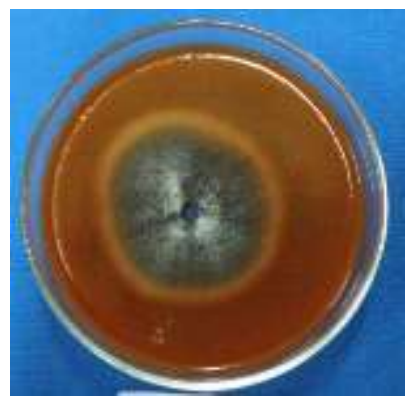

f

Gambar 1. Hasil seleksi khamir antagonis yang mencegah total pertumbuhan C. capsici menggunakan uji sumur pada media PDA yang mengandung $15 \%$ jus cabai merah setelah 7 hari inkubasi pada suhu $28 \pm 2{ }^{0} \mathrm{C}$. Isolat khamir CMM-1 (a); CMM-3 (b); CMM-4 (c); TMM-1 (d); EMM-11 (e); kontrol (pada sumur hanya ditempatkan suspensi konidium C. capsici) (f). 
Hasil analisis ragam menunjukkan bahwa luas gejala antraknosa pada buah cabai merah varietas Gada yang disebabkan oleh perlakuan C. capsici dan isolat khamir CMM1 dan kontrol negatif berbeda sangat nyata pada taraf kepercayaan 99\%. Isolat CMM-1 tidak dapat menghambat total pertumbuhan $C$. capsici pada buah cabai merah varietas Gada, namun isolat ini dapat menghambat perkembangan antraknosa sebesar $84.10 \%$ (Tabel 3). Isolat CMM-3, CMM-4, TMM-1, dan EMM-11 dapat menghambat total pertumbuhan $C$. capsici pada buah cabai merah var. Gada, karena berdasarkan pengamatan secara visual tidak ada gejala antraknosa pada permukaan buah cabai setelah 7 hari inkubasi. Keempat isolat ini menyebabkan persentase hambatan gejala antraknosa yang sama dengan fungisida benomil $0.5 \%$ sehingga berpotensi sebagai agens pengendalian hayati.

\section{Mekanisme Antagonisme Khamir terhadap C. capsici}

Interaksi antara isolat khamir CMM-3, CMM-4, TMM-1, dan EMM-11 dengan $C$. capsici menghasilkan tipe interaksi inhibisi patogen yang memenuhi kriteria interaksi tipe E dan F (Wheeler dan Hocking, 1993, dimodifikasi dari Magan dan Lacey, 1984). Interaksi yang dihasilkan memenuhi kriteria tipe E karena C. capsici tidak mengalami pertumbuhan lagi, dan memenuhi kriteria tipe
F karena setiap isolat khamir mengalami pertumbuhan melewati $C$. capsici dengan cara mengelilingi koloni $C$. capsici. Berdasarkan pengamatan secara visual, koloni keempat isolat khamir dan C. capsici saling kontak tanpa membentuk zona hambatan (Gambar 2). Persaingan ruang dan nutrisi diduga merupakan mekanisme antagonisme antara keempat isolat khamir dengan C. capsici. Hal ini dapat dilihat pada uji sumur dan uji pengendalian hayati $C$. capsici in vivo. Isolat khamir dapat mengkolonisasi dengan cepat, menggunakan ruang dan nutrisi yang tersedia pada media PDA yang mengandung 15\% jus buah cabai merah dan pada luka yang terdapat di buah cabai merah besar var. Gada sehingga dapat menghambat pertumbuhan $C$. capsici. Hal ini sesuai dengan Bleve et al. (2006) yang menyatakan bahwa khamir mampu mengkolonisasi dengan cepat pada luka yang terdapat pada permukaan buah-buahan dan sayuran dan menggunakan nutrisi yang tersedia sehingga dapat mencegah pertumbuhan cendawan patogen. Chalutz et al. (1988) juga melaporkan bahwa kompetisi ruang dan nutrisi merupakan mekanisme dasar dalam penghambatan patogen oleh khamir. Mekanisme hambatan lainnya adalah produksi kitinase, pelekatan pada dinding sel cendawan, aktivitas peroksidase, induksi ketahanan (El Gouth et al., 2003), dan menghasilkan sekresi yang menghambat pertumbuhan patogen (Guetsky et al., 2002).

Tabel 3. Hasil uji pengendalian hayati $C$. capsici menggunakan khamir in vivo pada buah cabai merah besar var. Gada setelah 7 hari inkubasi pada suhu $28 \pm 2{ }^{\circ} \mathrm{C}$ dengan kelembaban relatif $90 \%$.

\begin{tabular}{lcc}
\hline \multicolumn{1}{c}{ Isolat Khamir + C. capsici, dan Kontrol } & $\begin{array}{c}\text { Luas Gejala } \\
\text { Antraknosa }\left(\mathrm{mm}^{2}\right)\end{array}$ & Hambatan $(\%)$ \\
\hline CMM-1 + C. capsici & $15.25 \pm 3.07 \mathrm{~b}$ & $84.10 \pm 3.67 \mathrm{~b}$ \\
CMM-3 + C. capsici & $0.00 \mathrm{c}$ & $100.00 \mathrm{c}$ \\
CMM-4 + C. capsici & $0.00 \mathrm{c}$ & $100.00 \mathrm{c}$ \\
TMM-1 + C. capsici & $0.00 \mathrm{c}$ & $100.00 \mathrm{c}$ \\
EMM-11 + C. capsici & $0.00 \mathrm{c}$ & $100.00 \mathrm{c}$ \\
Kontrol negatif $($ C. capsici) & $96.61 \pm 6.54 \mathrm{a}$ & $0.00 \mathrm{a}^{*}$ \\
Kontrol positif (benomil 0.5\%+ C. capsici) & $0.00 \mathrm{c}$ & $100.00 \mathrm{c}$ \\
\hline Keterangan: Angka-angka pada kolom yang sama yang diikuti oleh huruf yang sama tidak berbeda nyata berdasarkan \\
\multicolumn{2}{c}{ uji banding Duncan pada taraf kepercayaan $99 \% ;{ }^{*}$ Asumsi persentase hambatan luas gejala antraknosa } \\
pada kontrol negatif $\left(96.6102 \mathrm{~mm}^{2}\right)$ adalah $0 \%$.
\end{tabular}




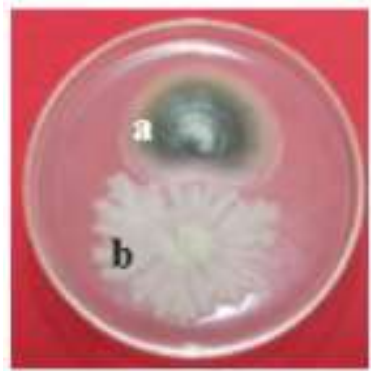

a

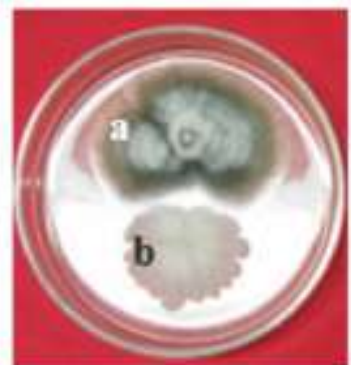

b

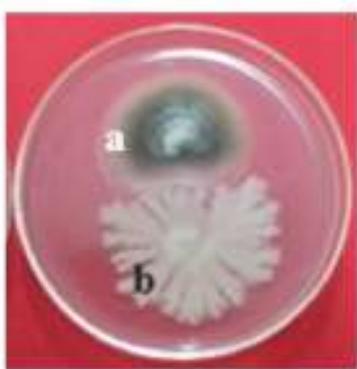

$\mathrm{c}$

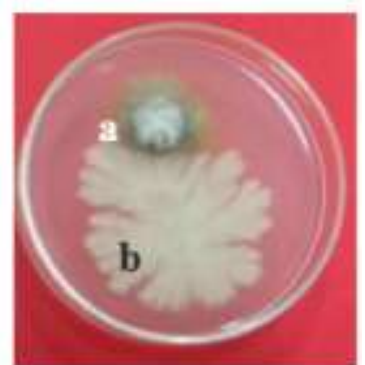

d

Gambar 2. Hasil uji mekanisme antagonisme antara khamir dengan C. capsici dengan tipe interaksi E dan F pada media PDA setelah 7 hari inkubasi pada suhu $28 \pm 2{ }^{\circ} \mathrm{C}$. CMM-3 vs $C$. capsici (a); CMM-4 vs $C$. capsici (b); TMM-1 vs $C$. capsici (c); EMM-11 vs $C$. capsici. $\mathrm{a}=$ C. capsici, $\mathrm{b}=$ isolat khamir.

\section{Identifikasi Khamir Antagonis}

Identifikasi secara morfologi terhadap 4 isolat khamir yang dapat mencegah total pertumbuhan $C$. capsici in vivo menunjukkan bahwa keempat isolat tersebut tergolong genus Issatchenkia. Koloni isolat CMM-3, CMM-4, TMM-1, dan EMM-11 pada media MEA setelah 7 hari inkubasi berwarna krem terang, berbentuk tak beraturan dan menyebar, memiliki tepi bergelombang, dan elevasi datar. Bentuk sel isolat CMM-3 dan TMM-1 adalah oval dan ukuran selnya 8.3-10.9 x 3.26-4.99 $\mu \mathrm{m}$, sedangkan isolat CMM-4 dan EMM-11 memiliki bentuk oval dan agak memanjang, ukuran selnya 9.33-11.93 x 4.39-5.97 $\mu \mathrm{m}$. Hasil identifikasi secara molekuler menunjukkan bahwa isolat CMM-3, CMM-4, TMM-1, dan EMM-11 adalah Issatchenkia orientalis karena berdasarkan analisis BLAST keempat isolat khamir memiliki tingkat kesamaan sikuen nukleotida dengan Issatchenkia orientalis (Pichia kudriazevii) sebesar 99\%. Panjang sikuen CMM-3, CMM4, TMM-1 dan EMM-11 masing-masing adalah 513, 515, 448 dan 513 bp (base pair). Hasil BLAST isolat CMM-3, CMM-4, TMM1 dan EMM-11 adalah sebagai berikut:

\section{Hasil BLAST isolat CMM-3:}

\begin{tabular}{|c|c|c|c|}
\hline Query & 1 & CTTCCGTAGGTGAACCTGCGGAAGGATCATTACTGTGATTTAGTACTACACTGCGTGAGC & 60 \\
\hline bjet & 1 & CTTCCGTAGGTGAACCTGCGGAAGGATCATTACTGTGATTTAGTACTACACTGCGTGAGC & 60 \\
\hline ery & 61 & $\begin{array}{l}\text { GGAACGAAAACAACAACACCTAAAATGTGGAATATAGCATATAGTCGACAAGAGAAATCT } \\
|||||||||||||||||||||||||||||||||||||||||||||||||||||||||||||||||||| \mid\end{array}$ & 20 \\
\hline bjct & 61 & GGAACGAAAACAACAACACCTAAAATGTGGAATATAGCATATAGTCGACAAGAGAAATCT & 120 \\
\hline ry & 121 & $\begin{array}{l}\text { ACGAAAAACAAACAAAACTTTCAACAACGGATCTCTTGGTTCTCGCATCGATGAAGAGCG } \\
||||||||||||||||||||||||||||||||||||||||||||||||||||||||||||||||||||)\end{array}$ & 80 \\
\hline bjet & 121 & ACGAAAAACAAACAAAACTTTCAACAACGGATCTCTTGGTTCTCGCATCGATGAAGAGCG & 80 \\
\hline uery & 181 & $\begin{array}{l}\text { CAGCGAAATGCGATACCTAGTGTGAATTGCAGCCATCGTGAATCATCGAGTTCTTGAACG } \\
|||||||||||||||||||||||||||||||||||||||||||||||||||||||||||||||||||| \mid\end{array}$ & 240 \\
\hline bjet & 181 & CAGCGAAATGCGATACCTAGTGTGAATTGCAGCCATCGTGAATCATCGAGTTCTTGAACG & 240 \\
\hline ry & 241 & $\begin{array}{l}\text { CACATTGCGCCCCTCGGCATTCCGGGGGGCATGCCTGTTTGAGCGTCGTTTCCATCTTGC } \\
||||||||||||||||||||||||||||||||||||||||||||||||||||||||||||||||||||||\end{array}$ & 300 \\
\hline bjet & 241 & CACATTGCGCCCCTCGGCATTCCGGGGGGCATGCCTGTTTGAGCGTCGTTTCCATCTTGC & 300 \\
\hline$r y$ & 301 & $\begin{array}{l}\text { GCGTGCGCAGAGTTGGGGGAGCGGAGCGGACGACGTGTAAAGAGCGTCGGAGCTGCGACT } \\
|||||||||||||||||||||||||||||||||||||||||||||||||||||||||||||||||||| \mid\end{array}$ & 360 \\
\hline & 1 & GCGTGCGCAGAGTTGGGGGAGCGGAGCGGACGACGTGTAAAGAGCGTCGGAGCTGCGACT & \\
\hline
\end{tabular}




\section{(Lanjutan hasil BLAST isolat CMM-3)}

\begin{tabular}{|c|c|c|}
\hline Query & 361 & 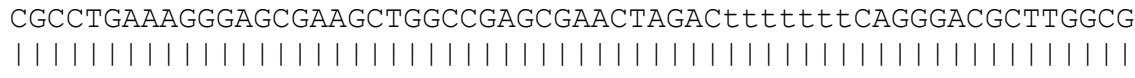 \\
\hline Sbjet & 361 & CGCCTGAAAGGGAGCGAAGCTGGCCGAGCGAACTAGACTTTTTTTCAGGGACGCTTGGCG \\
\hline Query & 421 & $\begin{array}{l}\text { GCCGAGAGCGAGTGTTGCGAGACAACAAAAAGCTCGACCTCAAATCAGGTAGGAATACCC } \\
|||||||||||||||||||||||||||||||||||||||||||||||||||||||||||||||||||| \mid\end{array}$ \\
\hline Sbjet & 421 & GCCGAGAGCGAGTGTTGCGAGACAACAAAAAGCTCGACCTCAAATCAGGTAGGAATACCC \\
\hline Query & 481 & $\begin{array}{l}\text { GCTGAACTTAAGCATATCAATAAGNCGGAGGAA } 513 \\
|||||||||||||||||||||||||||||||||||| \mid\end{array}$ \\
\hline bjet & 481 & ACTTAAGCATATCAATAAGGCGGAGGAA \\
\hline
\end{tabular}

\section{Hasil BLAST isolat CMM-4:}

\begin{tabular}{|c|c|c|}
\hline uery & 3 & 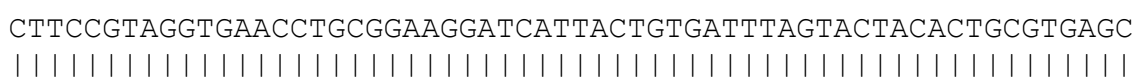 \\
\hline Sbjet & 1 & CTTCCGTAGGTGAACCTGCGGAAGGATCATTACTGTGATTTAGTACTACACTGCGTGAGC \\
\hline uery & 63 & GGAACGAAAACAACAACACCTAAAATGTGGAATATAGCATATAGTCGACAAGAGAAATCT \\
\hline Sbjet & 61 & $\begin{array}{l}|||||||||||||||||||||||||||||||||||||||||||||||||||||||||||||||||||| \\
\text { GGAACGAAAACAACAACACCTAAAATGTGGAATATAGCATATAGTCGACAAGAGAAATCT }\end{array}$ \\
\hline Query & 123 & 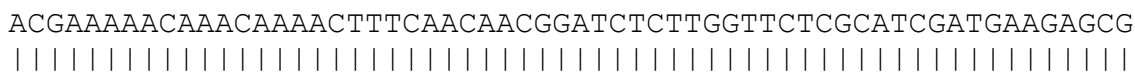 \\
\hline Sbjet & 121 & ACGAAAAACAAACAAAACTTTCAACAACGGATCTCTTGGTTCTCGCATCGATGAAGAGCG \\
\hline Query & 183 & 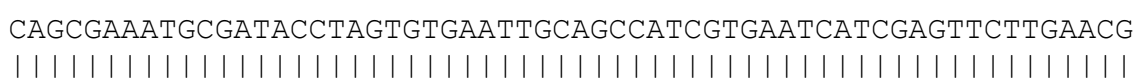 \\
\hline Sbjct & 181 & CAGCGAAATGCGATACCTAGTGTGAATTGCAGCCATCGTGAATCATCGAGTTCTTGAACG \\
\hline Query & 243 & 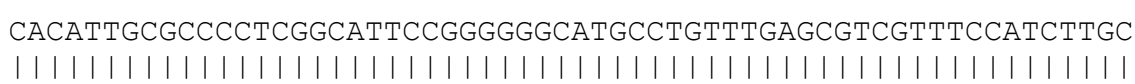 \\
\hline Sbjet & 241 & CACATTGCGCCCCTCGGCATTCCGGGGGGCATGCCTGTTTGAGCGTCGTTTCCATCTTGC \\
\hline Query & 303 & 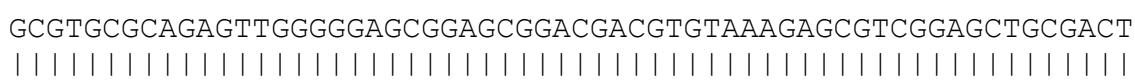 \\
\hline Sbjet & 301 & GCGTGCGCAGAGTTGGGGGAGCGGAGCGGACGACGTGTAAAGAGCGTCGGAGCTGCGACT \\
\hline Query & 363 & $\begin{array}{l}\text { GAAAGGGAGCGAAGCTGGCCGAGCGAACTAGACtttttttCAGGGACGCTTGGCG } \\
||||||||||||||||||||||||||||||||||||||||||||||||||||||||||||||||||||||\end{array}$ \\
\hline Sbjct & 361 & CGCCTGAAAGGGAGCGAAGCTGGCCGAGCGAACTAGACTTTTTTTCAGGGACGCTTGGCG \\
\hline Query & 423 & 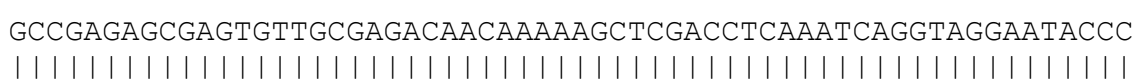 \\
\hline Sbjct & 421 & GCCGAGAGCGAGTGTTGCGAGACAACAAAAAGCTCGACCTCAAATCAGGTAGGAATACCC \\
\hline Query & 483 & $\begin{array}{l}\text { GCTGAACTTAAGCATATCAATAAGCCGGAGGAA } 515 \\
|||||||||||||||||||||||||||||||||| \mid\end{array}$ \\
\hline bjet & 481 & GCTGAACTTAAGCATATCAATAAGGCGGAGGAA 513 \\
\hline
\end{tabular}

\section{Hasil BLAST isolat TMM-1:}

Query 3

Sbjet 1

Query 63

sbjet 61
CTTCCGTAGGGGAACCTGCGGAAGGATCATTACTGTGATTTATATCTTATACACATGCGT |||||||||| |||||||||||||||||||||||||||||||||||||||||||||||||||||| CTTCCGTAGGTGAACCTGCGGAAGGATCATTACTGTGATTTATATCTTATACACATGCGT GAGCGCACCAAACACCTAAAATTGTAATACCACCAGTCACTAAGTTTTAACAAAACAAAA |||||||||||||||||||||||||||||| ||||||||||||||||||||||||||||||| GAGCGCACCAAACACCTAAAATTGTAATACTACCAGTCACTAAGTTTTAACAAAACAAAA 


\section{(Lanjutan hasil BLAST isolat TMM-1)}

\begin{tabular}{|c|c|c|}
\hline uery & 123 & 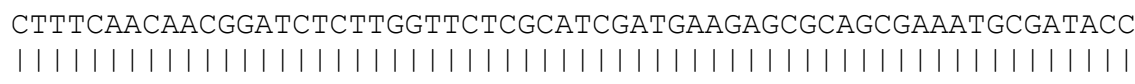 \\
\hline bjet & 121 & CTTTCAACAACGGATCTCTTGGTTCTCGCATCGATGAAGAGCGCAGCGAAATGCGATACC \\
\hline dery & 183 & $\begin{array}{l}\text { TAGTGTGAATTGCAGCCATCGTGAATCATCGAGTTCTTGAACGCACATTGCGCCCCATGG } \\
|||||||||||||||||||||||||||||||||||||||||||||||||||||||||||||||||||||||||||||||| l|l|\end{array}$ \\
\hline Sbjet & 181 & TAGTGTGAATTGCAGCCATCGTGAATCATCGAGTTCTTGAACGCACATTGCGCCCCATGG \\
\hline uery & 243 & $\begin{array}{l}\text { TATTCCATGGGGCATGCCTGTCTGAGCGTCGTTTCCTTCTTGCGCAAGCAGAGTTGAGA } \\
|||||||||||||||||||||||||||||||||||||||||||||||||||||||||||||||||||||||||||||||||||l|\end{array}$ \\
\hline Sbjet & 241 & TATTCCATGGGGCATGCCTGTCTGAGCGTCGTTTCCTTCTTGCGCAAGCAGAGTTGAGAA \\
\hline uery & 303 & $\begin{array}{l}\text { CAGGCTATGCCTTTTCGAAATGAACGTCGTGGACGAAGGAACTAAACTTTAGCACG } \\
|||||||||||||||||||||||||||||||||||||||||||||||||||||||||||||||||||||||||||||||||||l|\end{array}$ \\
\hline bjet & 301 & CAGGCTATGCCTTTTTCGAAATGGAACGTCGTGGACGAAGTGAACTAAACTTTTAGCACG \\
\hline ory & 363 & $\begin{array}{l}\text { CTTTGGCCGCCGACTTTTAACTAAGCTCGACCTCAGATCAGGTAGGATACCCGCTGA } \\
|||||||||||||||||||||||||||||||||||||||||||||||||||||||||||||||||||||||||||||||||||| l \mid\end{array}$ \\
\hline in & 361 & CTTTGGCCGCCGAACTTTTAACTAAGCTCGACCTCAGATCAGGTAGGAATACCCGCTGAA \\
\hline lery & 423 & $\begin{array}{l}\text { CTTAAGCATATCAATAAGCGGAGGAA } 448 \\
|||||||||||||||||||||||||||| \mid\end{array}$ \\
\hline i. & 421 & CTTAAGCATATCAATAAGCGGAGGAA 446 \\
\hline
\end{tabular}

\section{Hasil BLAST isolat EMM-11:}

\begin{tabular}{|c|c|c|}
\hline Query & 2 & $\begin{array}{l}\text { TTCCGTAGGGTGAACCTGCGGAAGGATCATTACTGTGATTTAGTACTACACTGCGTGAGC } \\
||||||||||||||||||||||||||||||||||||||||||||||||||||||||||||||||||||||\end{array}$ \\
\hline Sbjet & 153 & TTCCGTAGG-TGAACCTGCGGAAGGATCATTACTGTGATTTAGTACTACACTGCGTGAGC \\
\hline Query & 62 & $\begin{array}{l}\text { GGAACGAAAACAACAACACCTAAAATGTGGAATATAGCATATAGTCGACAAGAGAAATCT } \\
||||||||||||||||||||||||||||||||||||||||||||||||||||||||||||||||||||\end{array}$ \\
\hline Sbjct & 212 & GGAACGAAAACAACAACACCTAAAATGTGGAATATAGCATATAGTCGACAAGAGAAATCT \\
\hline Query & 122 & $\begin{array}{l}\text { ACGAAAAACAAACAAAACTTTCAACAACGGATCTCTTGGTTCTCGCATCGATGAAGAGCG } \\
|||||||||||||||||||||||||||||||||||||||||||||||||||||||||||||||||||||||||| \mid\end{array}$ \\
\hline Sbjct & 272 & ACGAAAAACAAACAAAACTTTCAACAACGGATCTCTTGGTTCTCGCATCGATGAAGAGCG \\
\hline Query & 182 & $\begin{array}{l}\text { CAGCGAAATGCGATACCTAGTGTGAATTGCAGCCATCGTGAATCATCGAGTTCTTGAACG } \\
|||||||||||||||||||||||||||||||||||||||||||||||||||||||||||||||||||| \mid\end{array}$ \\
\hline Sbjet & 332 & CAGCGAAATGCGATACCTAGTGTGAATTGCAGCCATCGTGAATCATCGAGTTCTTGAACG \\
\hline Query & 242 & $\begin{array}{l}\text { CACATTGCGCCCCTCGGCATTCCGGGGGGCATGCCTGTTTGAGCGTCGTTTCCATCTTGC } \\
||||||||||||||||||||||||||||||||||||||||||||||||||||||||||||||||||||||\end{array}$ \\
\hline Sbjet & 392 & CACATTGCGCCCCTCGGCATTCCGGGGGGCATGCCTGTTTGAGCGTCGTTTCCATCTTGC \\
\hline Query & 302 & $\begin{array}{l}\text { GCGTGCGCAGAGTTGGGGGAGCGGAGCGGACGACGTGTAAAGAGCGTCGGAGCTGCGACT } \\
||||||||||||||||||||||||||||||||||||||||||||||||||||||||||||||||||||||||||||\end{array}$ \\
\hline Sbjet & 452 & GCGTGCGCAGAGTTGGGGGAGCGGAGCGGACGACGTGTAAAGAGCGTCGGAGCTGCGACT \\
\hline Query & 362 & $\begin{array}{l}\text { CGCCTGAAAGGGAGCGAAGCTGGCCGAGCGAACTAGACtt t t tCAGGGACGCTTGGCG } \\
||||||||||||||||||||||||||||||||||||||||||||||||||||||||||||||||||||)\end{array}$ \\
\hline Sbjet & 512 & CGCCTGAAAGGGAGCGAAGCTGGCCGAGCGAACTAGACTTTTTTTCAGGGACGCTTGGCG \\
\hline Query & 422 & $\begin{array}{l}\text { GCCGAGAGCGAGTGTTGCGAGACAACAAAAAGCTCGACCTCAAATCAGGTAGGAATACCC } \\
|||||||||||||||||||||||||||||||||||||||||||||||||||||||||||||||||||||| \mid)\end{array}$ \\
\hline Sbjet & 572 & GCCGAGAGCGAGTGTTGCGAGACAACAAAAAGCTCGACCTCAAATCAGGTAGGAATACCC \\
\hline Query & 482 & $\begin{array}{l}\text { GCTGAACTTAAGCATATCAATAAGCGGAGGAA } \\
|||||||||||||||||||||||||||||||||||| \mid)\end{array}$ \\
\hline sbjet & 632 & GCTGAACTTAAGCATATCAATAAGCGGAGGAA 663 \\
\hline
\end{tabular}




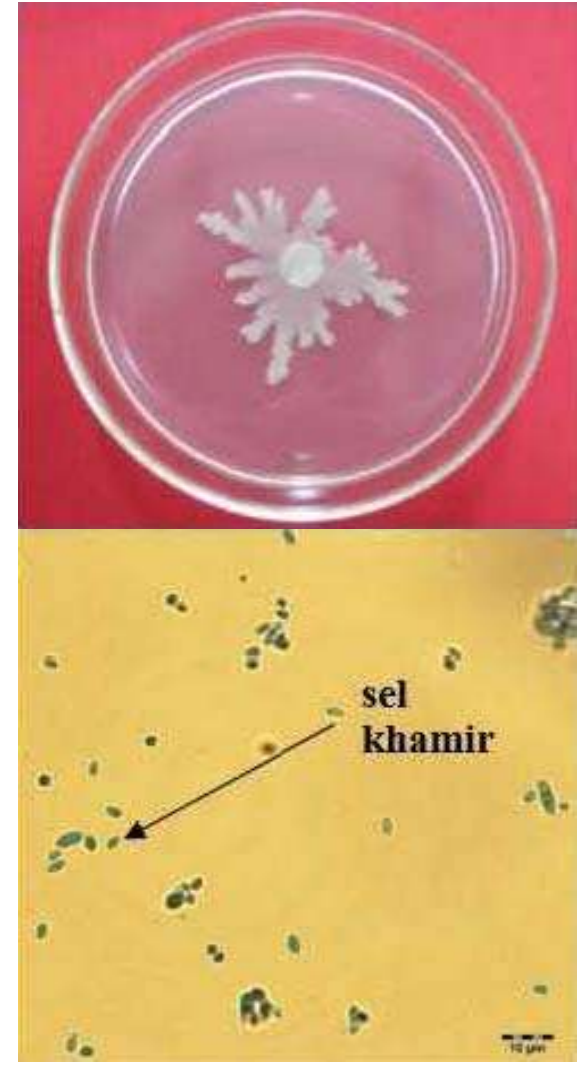

Gambar 3. Biakan murni Issatchenkia orientalis isolat CMM-3 pada media Malt Extract Agar (MEA) setelah 7 hari inkubasi pada suhu $28 \pm 2{ }^{0} \mathrm{C}$ (a); Foto mikrograf Issatchenkia orientalis isolat CMM-3 (1 000x) (b).

Bleve et al. (2006) melaporkan bahwa I. orientalis galur $16 \mathrm{C} 2$ dan $2 \mathrm{C} 2$ yang diisolasi dari buah anggur dapat mereduksi kolonisasi cendawan Aspergillus carbonarius dan A. niger pada buah anggur. Issatchenkia orientalis galur ER1 yang diisolasi dari terung ungu dapat mereduksi timbulnya antraknosa pada buah cabai sebesar $76.6 \%$ (Chanchaichaovivat et al., 2007).

\section{KESIMPULAN}

Lima dari 22 isolat khamir yang diisolasi dari buah-buahan dan sayuran, yaitu CMM-1, CMM-3, CMM-4, TMM-1, dan EMM-11 dapat menghambat total pertumbuhan $C$. capsici setelah inkubasi 7 hari pada uji sumur. Isolat CMM-3, CMM-4, TMM-1, dan EMM-11 dapat menekan total serangan antraknosa pada buah cabai merah besar varietas Gada sehingga keempat isolat tersebut berpotensi sebagai agens pengendalian hayati antraknosa pada buah cabai merah. Berdasarkan hasil identifikasi secara morfologi dan molekuler, isolat CMM3, CMM-4, TMM-1, dan EMM-11 adalah Issatchenkia orientalis.

\section{UCAPAN TERIMA KASIH}

Penulis mengucapkan terima kasih kepada Ir. Ina Retnowati dan Nijma Nurfadila, SSi atas bantuan teknis; dan kepada Dr. Utut Widyastuti, MSi (Almh.) yang telah membantu mengidentifikasi khamir secara molekuler.

\section{DAFTAR PUSTAKA}

Bleve, G., F. Grieco, G. Cozzi, A. Logrieco, A. Visconti. 2006. Isolation of epiphytic yeast with potential for biocontrol of Aspergillus carbonarius and A. niger on grape. J. Food Microbiol. 108: 204-209.

Chalutz E., A.R. Ben, S. Droby, L. Cohen, B. Weiss, C.L. Wilson. 1988. Yeast as biocontrol agents of postharvest diseases of fruits. Phytoparasitica. 16: 69.

Chanchaichaovivat, A., B. Panijpan, P. Ruenwongsa. 2007. Screening and identification of yeast strains from fruits and vegetables: potential for biological control of postharvest chilli anthracnose (Colletotrichum capsici). Biol. Control. 42: 326-335.

[Ditbenih] Direktorat Perbenihan Hortikultura. 2014. Database Varietas. http://ditbenih. hortikultura.deptan.go.id [12 Maret 2015].

[Ditbuah] Direktorat Budidaya dan Pascapanen Buah. 2012. Pedoman Penanganan Pascapanen Pisang. http:// ditbuah.hortikulturapertanian.go.id [11 Maret 2015].

Dan, H., X.D. Zhenk, Y.M. Yin, P. Sun, H.Y. Zhang. 2003. Yeast application for controlling apple postharvest disease associated with Penicillium expansum. Bot. Bull. Acad. Sin. 44: 211-216. 
El Gouth, A., C.L. Wilson, M. Wisniewski. 2003. Control of postharvest decay of apple fruit with Candida saitoama and induction of defense responses. J. Phytopathol. 93: 344-348.

Guetsky, R., D. Shtienberg, Y. Elad, E. Fischer, A. Dinoor. 2002. Improving biological control by combining biocontrol agents each with several mechanisms of disease suppression. J. Phytopathol. 92: 976-985.

Hashem, M., S. Alamri. 2009. The biocontrol of postharvest disease (Botryodiplodia theobromae) of guava (Psidium guajava) by the application of yeast strains. Postharvest Biol. Technol. 53: 123-130.

Harsono, P. 2012. Mulsa organik: pengaruhnya terhadap lingkungan mikro, sifat kimia tanah dan keragaan cabai merah di tanah vertisol Sukoharjo pada musim kemarau. J. Hort. Indonesia. 3(1): 35-41.

Janisiewicz, W.J., L. Korsten. 2002. Biological control of postharvest diseases of fruits. Ann. Rev. Phytopathol. 40(1): 14-41.

[Kementan] Kementrian Pertanian. 2015. Produksi Cabai Besar Menurut Provinsi, 2010-2014. http://www.pertanian.go.id. [19 Juni 2015].

Khalimi, K. 2010. Pemanfaatan ragi (Saccharomyces sp.) dalam pengendalian penyakit tumbuhan yang ramah lingkungan. J. Bumi Lestari. 10(2): 215221.

Kurtzman, C.P., J.W. Fell, T. Boekhout. 2011. The Yeasts, A Taxonomic Study. Edisi ke-5. London (GB): Elsevier.
Magan, N., J. Lacey. 1984. The effect of water activity, temperature and structure on interactions between field and storage fungi. Trans. Brit. Mycol. Soc. 92: 83-93.

Mattjik, A.A., I.M. Sumertajaya. 2002. Perancangan Percobaan dengan Aplikasi SAS dan Minitab. Ed ke-2. Bogor (ID): IPB Pr.

Mitchell, T.G., T.J. White, J.W. Taylor. 1992. Comparison of $5.8 \mathrm{~S}$ ribosomal DNA sequences among the Basidiomycetous yeast genera Cystofilobasidium, Filobasidium, and Filobasidiella. J. Med. Vet. Mycol. 30: 207-208.

Pal, K.K., B.M. Gardener. 2006. Biological Control of Plant Pathogens. The Plant Health Instructor. DOI: 10.1094/PHI-A2006-1117-02.

Rindita, L.I., Sudirman, Y. Koesmaryono. 2015. Air quality bioindikator using the population of epiphytic macrolichens in Bogor City, West Java. Hayati J. Biosci. 22 (2): 53-59.

Sharma, R.R., D. Singh, R. Singh. 2009. Biological control of postharvest diseases of fruits and vegetables by microbial antagonists: A review. J. Biocontrol. 50: 205-221.

Wheeler, K.A., A.D. Hocking. 1993. Interactions among xerophilic fungi associated with dried salted fish. J. Applied Bacteriol. 74: 164-169.

Wilia, W., Widodo, S. Wiyono. 2012. Potensi khamir untuk mengendalikan penyakit antraknosa (Colletotrichum acutatum L.) pada tanaman cabai. Bioplantae. 1(4): 291-298. 